\title{
Core Biopsy of Bone
}

National Cancer Institute

\section{Source}

National Cancer Institute. Core Biopsy of Bone. NCI Thesaurus. Code C159487.

The removal of bone marrow tissue using a needle with a relatively large diameter, for microscopic examination. 